\title{
Nitrooxidative Stress and Neurodegeneration
}

\author{
Michal Fiedorowicz and Pawel Grieb \\ Mossakowski Medical Research Centre, Polish Academy of Sciences, Warsaw \\ Poland
}

\section{Introduction}

Stress is the force on unit areas within a material that develops as a result of the externally applied force (Enciclopedia Britannica, 2011).

When I wrote the first paper on the stress syndrome in 1936, I tried to demonstrate that stress (...) is clearly a definable biological and medical phenomenon whose mechanisms can be objectively identified and with which we can cope much better once we know how to handle it (...) Stress is the nonspecific response of the body to any demand, whether is caused by, or results in, pleasant or unpleasant conditions (Selye, 1985).

Oxidative stress is defined as a persistent imbalance between antioxidants and pro-oxidants in favor of the latter, resulting in (often) irreversible cellular damages (Probiox, 2011).

Nitrosative Stress: A condition that occurs when the production of highly reactive nitrogencontaining chemicals, such as nitrous oxide, exceed the ability of the (...) body to neutralize and eliminate them. Nitrosative stress can lead to reactions that alter protein structure thus interfering with normal body functions (Oxford Dictionary of Sports Science \& Medicine, 2007).

The four quotations collected above illustrate confusion with the notion of stress. In physics, in Hooke's law, 'stress' means a force acting on an elastic material and producing a proportional amount of deformation, or strain. However, according to Selye, who introduced the notion of 'stress' into (bio)medicine, it is not a kind of force acting on an organism (such force is called 'stressor'), but a response of an organism to such a force. In fact, Selye's definition of 'stress' is more similar to the notion of 'strain' in Hooke's law. Contemporary uses of the term 'stress' in biomedical scientific literature are very diverse; the last two examples define stress as an imbalance which occurs inside a body and leads to its damage. These definitions are very different from Selye's definition of stress.

Several distinguished authors wrote reviews about oxidative and nitrosative stress, but many either did not define these terms at all, or defined them vaguely and indirectly. For example, in a recent review one of the most prominent biochemists working in the field of redox and free radicals biochemistry professor Barry Halliwell only listed reasons why tissue injury causes oxidative stress and what oxidative stress means in the context of human disease (Halliwell, 2009); it seems that he implicitly defined oxidative stress as a result of tissue injury (or, perhaps, response to it) rather than its cause. However most 
authors, indeed, use terms 'oxidative stress' and 'nitrosative stress' to describe situations of persistent imbalance between production and removal of oxidising free radicals leading to their increased level and resulting in harmful effects on biological molecules, cells and tissues. For example professor Helmut Sies defined 'oxidative stress' as a condition occurring when the generation of reactive oxygen species (ROS) in a system exceeds the system's ability to neutralize and eliminate them. This imbalance can result from a lack of antioxidant capacity caused by disturbance in production, distribution, or by an overabundance of ROS from endogenous sources or environmental stressors (Brenneisen et al., 2005; Sies, 1997). Shouldn't we conclude that oxidative stress is always linked to the damage of biological macromolecules and the disruption of cellular homeostasis? However, the title of the other paper from Sies's laboratory includes the phrase "Peroxynitrite signalling: (...) activation of stress-responsive pathways" (Klotz et al., 2002), which is suggestive of that cells not only receive harm from nitrooxidative stress but also can respond to in an orderly manner, which depends on circumstances and may be either positive or detrimental.

Concise and amazingly fitting definition of the term 'stress' we found in the English-Polish dictionary (Stanislawski, 1999). This definition, translated back to English, reads the following: 'stress is the pressure of circumstances'. In the case of oxidative and nitrosative stress the said circumstances are disturbances in the balance between production and removal of reactive forms of oxygen and nitrogen, most of which are free radicals. The amount of literature on this subject is so large, that its comprehensive review would require a multi-thousand-page book. In the present chapter we will concentrate on the following specific subjects: (1) why nitrooxidative stress is considered harmful, (2) cellular metabolism of reactive oxygen and nitrogen species, and (3) how nitrooxidative stress can contribute to some major neurodegenerative diseases.

\section{Free radicals}

The recent version of the International Union of Pure and Applied Chemistry (IUPAC) Recommendations on Nomenclature of Inorganic Chemistry (IUPAC, 2005), known as the Red Book, defines a radical as an atom or molecule with one or more unpaired electrons. An unpaired electron may be indicated in a formula by a superscript dot. A radical may have positive, negative or zero charge. Metals and their ions or complexes often possess unpaired electrons but, by convention, they are not considered to be radicals. The terms 'radical' and 'free radical' are frequently used interchangeably, although more correctly radicals may be called 'free' only when they can freely diffuse in their environment.

The aforementioned definition is also strictly applicable to organic radicals, i.e. radicals containing carbon. However, we shall bear in mind that not long time ago such a view was difficult to accept. This was because, after many futile attempts to isolate carbon-containing radicals, XIX-century chemists concluded that carbon must always be tetravalent (i.e. form four bonds) and organic radicals cannot exist. Although the first organic free radical, the trityl (triphenylmethyl) radical (fig. 1), was discovered by Gomberg in 1900, for many years this discovery was viewed only as a curiosity (Henderson, 2000). Besides, trityl radical does not contain oxygen. 


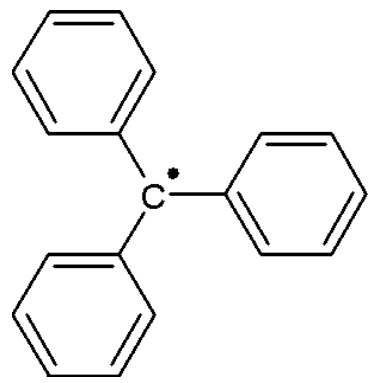

Fig. 1. Trityl (triphenylmethyl) radical.

The concept of oxygen free radicals toxicity as the major contributor to various pathologies has been developed in the middle of XX century, at the intersection of studies on mechanisms of oxygen toxicity and on toxic effects of ionizing radiation. On one hand, it was already very well known that eukaryotic organisms cannot survive without oxygen, yet at the same time oxygen is toxic. This Janus-faced property of oxygen is sometimes called the 'paradox of aerobic life', or the 'oxygen paradox' (Fridovich, 1975). Toxic effects of exposure to oxygen at increased partial pressure, particularly evident in human central nervous system and lungs, have been described in the late XIX century, but after more than 50 years their mechanism remained unknown (Donald, 1947). On the other hand, harmful effects on living organisms of ionizing radiation, which become known shortly after its discovery (Inkret et al., 1995), were already explained, mostly by the intracellular radiolysis of water molecules into $\mathrm{H}^{+}$and $\mathrm{OH}^{-}$radicals. These radicals either by itself cause oxidative damage to the cells, or further recombine to nascent toxic radicals such as superoxide.

In 1954 the presence of free radicals in biological materials not subjected to ionizing radiation was discovered (Commoner et al., 1954). Almost at the same time Gershman, Gilbert and collaborators put forward a hypothesis that the majority of harmful effects of both oxygen and ionizing radiation could be attributed to the same mechanism, namely the formation of oxygen radicals (Gerschman et al., 1954). This hypothesis was later developed into the theory that oxygen radicals are continuously generated in all living cells, starting point of their cellular metabolism being the formation of superoxide radical anion (Fridovich, 1983). Halliwell and Gutteridge (1984) called this concept 'the superoxide theory of oxygen toxicity'. Currently it is generally accepted that oxygen free radicals are ubiquitous in the living matter; they are continuously produced by a variety of reactions (enzymatic and nonenzymatic), and at the same time continuously removed by the other variety of reactions. Indeed, the generation of oxygen radicals in living cells is not a pathology, but the fundamental physiological phenomenon.

Moreover, molecular oxygen $\left(\mathrm{O}_{2}\right)$ by itself is a double radical (a biradical), having two unpaired electrons with parallel spin states. This arangement is quite fortunate, as it makes $\mathrm{O}_{2}$ a stable radical and prevents spontaneous ignition of carbon-based materials in the oxygen atmosphere. On the other hand, as a consequence, oxidation by molecular 
oxygen can easily occur only by the transfer of single electrons. However, organic molecules which are substrates for biological oxidations do not contain unpaired electrons. Therefore molecular oxygen could accept a pair of electrons from an organic substrate only when one of the electrons of oxygen or one of the electrons from the donating substrate inverts its spin. This can happen, but would require a substantial activation energy.

The solution utilised by living cells to decrease activation energy for oxidations relies on conducting two oxidations stepwise, by a close sequence of two single-electron transfers (Miles, 2003). This arrangement works nicely, but its side effect is a relatively high probability that products of the first one-electron reduction of oxygen, i.e. oxygen radicals, will not engage in the second one-electron reduction step but enter the intracellular (or extracellular) milieu instead.

As mentioned already, oxygen free radicals have potential to react with (that is, to oxidize) practically any organic molecule they come in contact with. These reactions may inflict damage to cellular constituents including macromolecules (proteins, nucleic acids), aminoacids, sugars, lipids (polyunsaturated fatty acids in particular) etc. However, under normal metabolic conditions the actual concentration of free radicals in biological matter (i.e. living cells and extracellular material) is pretty small. Chance et al. (1979) estimated that in rat liver equilibrium concentration of superoxide anion radical is in the order of $10^{-12}$ to 10-11 $\mathrm{M}$ and that of hydrogen peroxide is only 3 orders of magnitude greater. Only if equilibrium is disturbed, which may be called nitrooxidative stress, oxygen free radicals and products of their metabolism which are strong oxidants, all called collectively reactive oxygen and nitrogen species (ROS and RNS), do have potential for inflicting damage to vital constituents of the living cells (McCord, 2000).

\section{Cellular metabolism of reactive oxygen and nitrogen species}

Reactions of ROS and RNS which occur in living cells are irreversible and may be presented as a cascade (fig. 2) that starts with generation of superoxide radical $\left(\mathrm{O}_{2}{ }^{-}\right)$. This free radical appears mainly in mitochondria; some authors estimate that $2-4 \%$ of oxygen metabolized by mitochondrial respiratory chain leaves it as superoxide (Turrens, 2003). $\mathrm{O}_{2}{ }^{\bullet}$ is also a product of certain enzymatic reactions localized outside mitochondria, in particular NADH oxidation conducted by non-mitochondrial NADH oxidases called NOX (Sorce \& Krause, 2009). Some NOX isoenzymes are end parts of 'plasma respiratory chains' called also 'plasma membrane oxidoreductases' (PMOR) present in many cell types including neurons (Wright \& Kuhn, 2002). ECTO-NOX present on cell surface are supposed to release $\mathrm{O}_{2}{ }^{\bullet}$ - into the extracellular milieu, while other isoforms of NOX produce superoxide radical intracellularly.

An additional source of superoxide radical is singlet oxygen $\left({ }^{1} \mathrm{O}_{2}\right)$, generated in photosensitization reaction which takes place in vivo upon exposure of cells to light, e.g. in the retina. Although not a free radical, ${ }^{1} \mathrm{O}_{2}$ is a highly reactive molecule, thus it belongs to ROS. Some authors claim that singlet oxygen by itself can damage membranes and other cell components (Winkler et al., 1999). Importantly, singlet oxygen cannot be removed enzymatically but only in reactions with non-enzymatic antioxidants. Singlet oxygen can be also reduced to $\mathrm{O}_{2}{ }^{\bullet}$. 


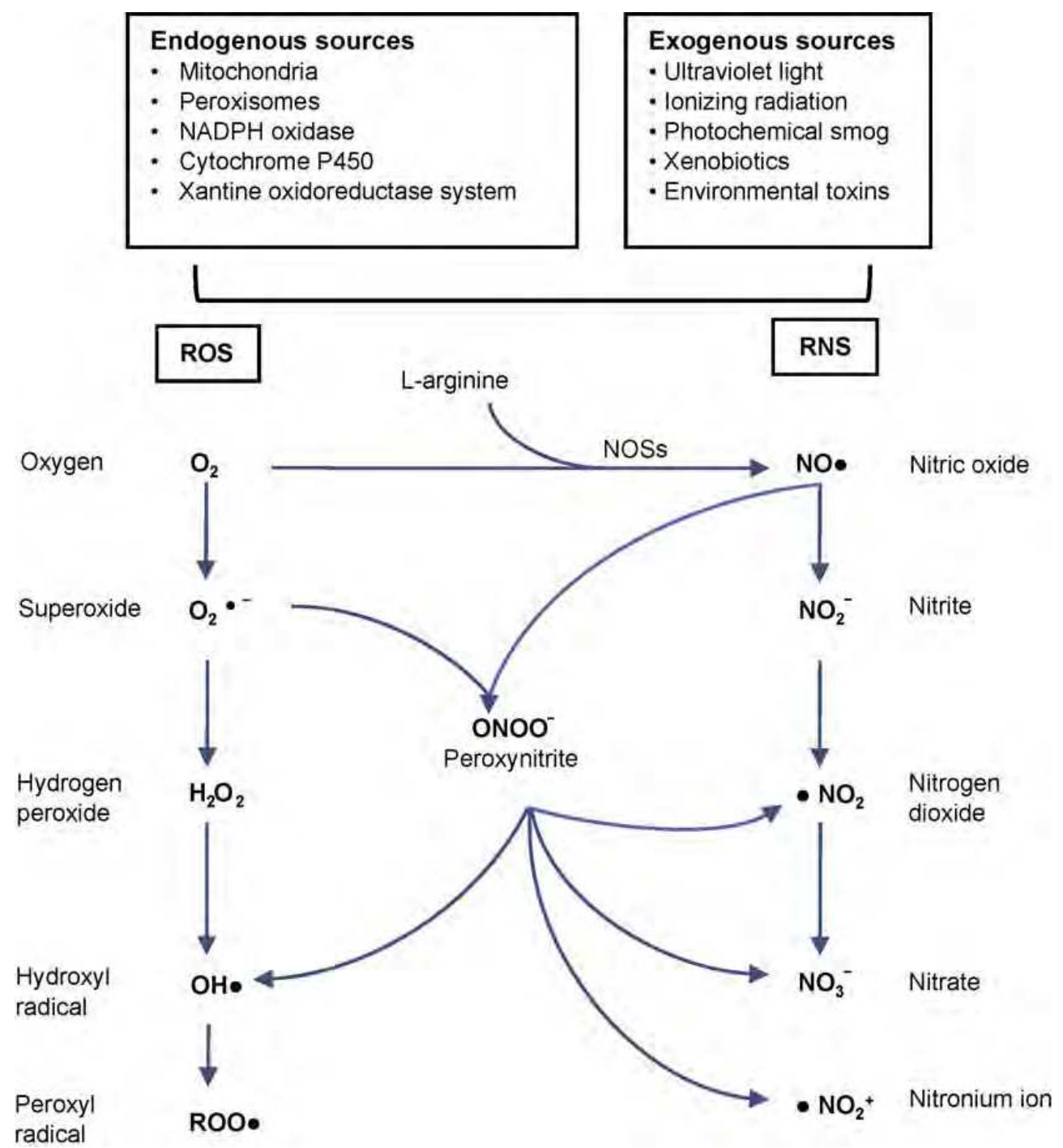

Fig. 2. Cascade of radical reactions in the cell and the most important reactive oxygen and nitrogen species. Main sources of ROS and RNS are listed in the upper part of the figure. Reproduced from Mangialasche et al. (2009). (C) Elsevier, with permission.

Cells can be damaged directly by superoxide radical (Benov, 2001), or by its metabolites, hydroxyl radical and peroxynitrites. Compared to other radicals superoxide is not very 
reactive chemically; moreover it may react only either with itself (dismutation), with another radical such as nitric oxide, or with a metal. Hovewer, although dismutation of $\mathrm{O}_{2}{ }^{\bullet-}$ occurs spontaneously, it is a second order reaction with respect to substrate concentration, ineffective in removing it at low concentrations. Since even in subnanomolar concentrations superoxide is toxic, in particular to some mitochondrial enzymes (e.g. aconitase), all cells are equipped with enzymes superoxide dismutases (SOD), which very efficiently convert superoxide to hydrogen peroxide (see below).

Of all ROS, hydrogen peroxide is a molecule with the longest half-life, and it may achieve the highest intracellular concentration. Moreover, it has the ability to diffuse across biological membranes. Hydrogen peroxide by itself is not particularly toxic or dangerous to the cells, but in reaction catalyzed by iron ions $\left(\mathrm{Fe}^{2+}\right)$ it is converted to hydroxyl radical $\left(\mathrm{OH}^{\bullet}\right)$ (Buonocore et al., 2010). This reaction, known as the Haber-Weiss reaction, generates hydroxyl radicals from $\mathrm{H}_{2} \mathrm{O}_{2}$ and superoxide. It can occur in cells, being responsible for oxidative stress. It is a two-step catalytic cycle. The first step involves reduction of ferric ion to ferrous:

$$
\mathrm{Fe}^{3+}+\mathrm{O}_{2}^{\cdot-} \rightarrow \mathrm{Fe}^{2+}+\mathrm{O}_{2}
$$

The second step, known as the Fenton reaction, regenerates ferric ion:

$$
\mathrm{Fe}^{2+}+\mathrm{H}_{2} \mathrm{O}_{2} \rightarrow \mathrm{Fe}^{3+}+\mathrm{OH}^{-}+\mathrm{OH}^{\bullet}
$$

Hydroxyl radical is regarded the most cell-damaging oxidant (Cheng et al., 2002). Its half life is extremely short $\left(10^{-6} \mathrm{~s}, 3\right.$ orders of magnitude shorter than $\left.\mathrm{O}_{2}{ }^{--}\right)$and it acts locally, very close to site of its generation. It reacts mainly with alkyl groups or with polyunsaturated fatty acids, initiating chain peroxidation (see below).

Peroxynitrite (ONOO-), the most important RNS, is a product of reaction of superoxide radical with nitric oxide. It is not a radical but is a potent oxidant and nitrating agent. It can nitrate tyrosine residues of proteins (generating nitrotyrosine) - this protein modification can affect enzyme activities and increase susceptibility of proteins to proteolysis (Abello et al., 2009). It also oxidizes fatty acids and induces DNA strand breaks (Ascenzi et al., 2010).

ROS and RNS react with many important biomolecules. Lipid chain peroxidation is particularly important since it affects functioning of biological membranes: their fluidity, permeability, ion transportation and inhibits metabolic processes. Peroxidation of mitochondrial membrane lipids (e.g. cardiolipin) may induce apoptosis (Kagan et al., 2009). Lipids containing polyunsaturated faty acids (PUFA) are particularly vulnerable to peroxidation. Lipid chain peroxidation consists of three phases: initiation, propagation and termination (fig. 3). Initiation phase includes hydrogen atom abstraction in reaction with diiferent radicals (e.g. $\left.\mathrm{OH}^{*}\right)$ and produces a lipid radical $\left(\mathrm{L}^{\cdot}\right) . \mathrm{L}^{\cdot}$ reacts with oxygen to produce lipid peroxyl radical (LOO*) that can abstract hydrogen atoms from another lipids to produce lipid hydroxyperoxide ( $\mathrm{LOOH}$ ) and another radical (propagation). This reaction can repeated many times - one hydroxyl radical can damage thousands of PUFA chains. The 'chain peroxidation' terminates when two radicals react together forming non-radical species (Catala, 2010). 


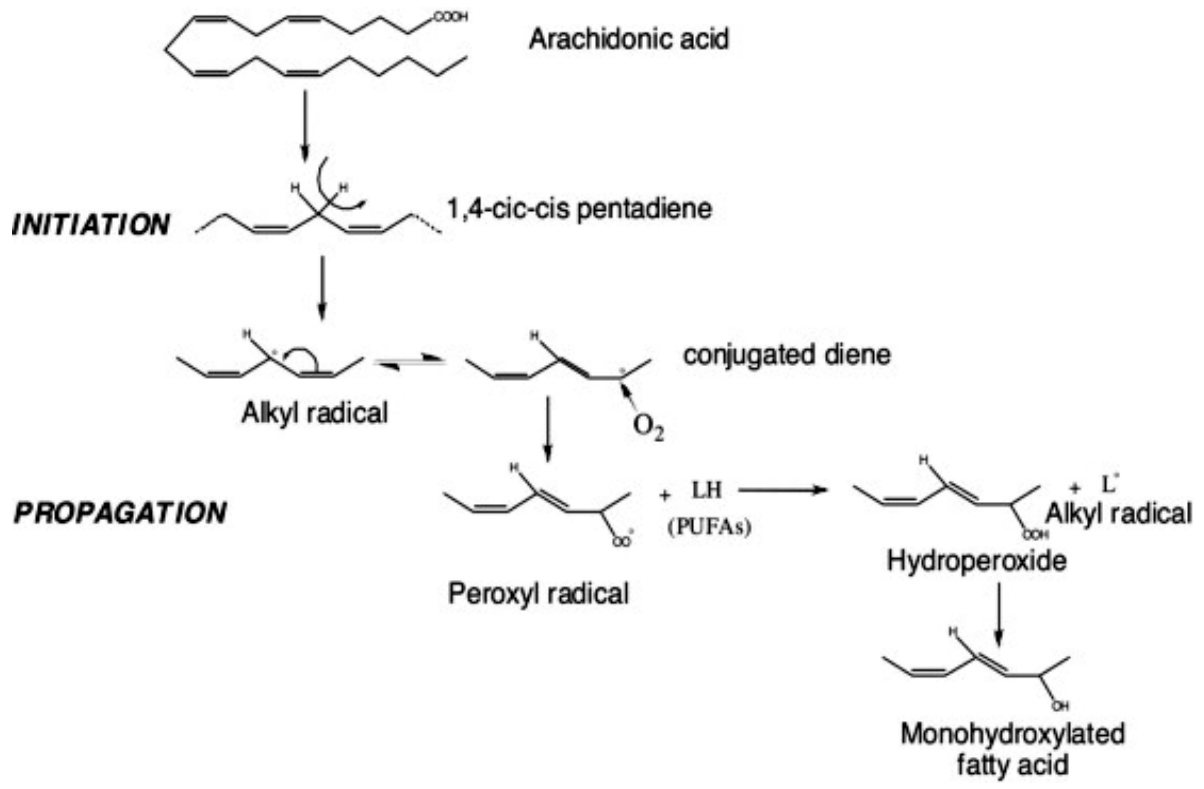

Fig. 3. Lipid peroxidation mechanism. Arachidonic acid was used as an example. Reproduced from Catala (2010). (c) Elsevier, with permission.

Cells possess various mechanisms responsible for minimizing free radical hazard - 'lowweight' non-catalytic antioxidants and antioxidant enzymes. Superoxide dismutases can be regarded as 'first line of defense' against ROS. This group of enzymes catalyze reaction of superoxide radical dismutation (i.e. conversion of $\mathrm{O}_{2} \cdot-$ to $\mathrm{H}_{2} \mathrm{O}_{2}$ ). Although this reaction occurs spontaneously, lack of catalyst would increase $\mathrm{O}_{2}{ }^{\bullet-}$ concentration, potentiate chain lipid peroxidation and lead to more intensive generation of RNS. Mammals possess three isoforms of superoxide dismutases: 'cytoplasmic' (CuZn-SOD, SOD1), 'mitochondrial' (MnSOD, SOD2) and 'extracellular' (EC-SOD, SOD3). Most of cellular dismutase activity (50$80 \%$ ) is attributed to SOD1 (Faraci \& Didion, 2004) but it is SOD2 that is thought to be crucial for cell functioning. SOD2 gene knockout was lethal in mice (Huang et al., 2001) and decrease in SOD2 activity (Sod2+/-) led to neuronal loss and cancer progression (Van Remmen et al., 2003).

It should be also stressed that recently ROS and RNS are regarded not only as toxic byproducts of metabolism but also as important signaling molecules. Two important and thoroughly examined ones are hydrogen peroxide and nitric oxide. Hydrogen peroxide has relatively long half-life and can penetrate biological membrane. Concentration of $\mathrm{H}_{2} \mathrm{O}_{2}$ in the cell is also relatively high. It is believed to be involved in various processes including immune cell activation, remodeling of vessels, cell growth and many others (see reviews by Veal et al. (2007) or by Giorgio et al. (2007)). Hydrogen peroxide level is precisely regulated 
by growth factors. It inhibits phosphatases that are involved in propagation of signal induced by growth factors. It also induces tyrosine phosphorylation by activation of MAP kinases.

Observation that at least some of ROS and RNS are important signaling molecules and their levels are precisely regulated in the cell leads to the idea of 'redox homeostasis'. It is hypothesized that ROS/RNS are especially involved in regulation of proliferation and cell death of cells (Clement \& Pervaiz, 1999). Reducing environment and low levels of ROS/RNS would suppress proliferation and is characteristic for 'resting' cells (see also fig. 7). Higher level of oxidants would promote proliferation and a bit higher apoptosis. However, above some range apoptosis would be suppressed due to oxidation of caspases (Hampton \& Orrenius, 1998).

\section{Nitrooxidative stress - Contribution to the pathomechanisms of neurodegenerative disorders}

Neurodegenerative diseases - innate or acquired disorders of nervous system - can be defined by degeneration and death of neuronal cells. There is a regional or even cell-typespecific selectivity of neuronal failure and loss in different diseases. For example in Alzheimer's disease loss of cholinergic neurons occur mainly in the forebrain, in Parkinson's disease dopaminergic neurons in substiantia nigra are selectively injured and in glaucoma retinal ganglion cells are degenerating. Neuronal tissue seems to be vulnerable to damage caused by reactive forms of oxygen and nitrogen: oxygen metabolism is high and neurons contain high amounts of PUFA. Also oxidative/nitrosative damage to the neuronal tissue seems to be an early hallmark of degeneration in different pathologies. Thus, despite regionspecific sensitivity, damage resulting from processes including ROS and RNS may be proposed as unifying mechanism for neurodegeneration (Ischiropoulos \& Beckman, 2003). Common mechanisms involved in neurodegenerative disease leading to oxidative stress could include the inhibition of mitochondrial metabolism, neuronal excitotoxicity, and neuroinflammation (Golden \& Patel, 2009). Examples further in this chapter show that nitrooxidative stress can be a key player in pathomechanisms of diverse neurodegenerative diseases.

\subsection{Nitrooxidative stress and Alzheimer's disease}

Alzheimer's disease (AD) is the most common type of dementia and in fact the most common neurodegenerative disorder. Most of the cases are sporadic but $5-10 \%$ of cases are familial and associated with mutations in genes of proteins involved in amyloid- $\beta$ (A $\beta$ ) metabolism. The disease is characterized by progressive cognitive decline and neuropathological alterations: senile plaques built up by $\mathrm{A} \beta$ peptide and neurofibrillary tangles composed of hyperphosphorylated tau protein. Gross brain atrophy prominent in $\mathrm{AD}$ is caused by massive loss of neurons mostly in the temporal lobe and parietal lobe, and parts of the frontal cortex and cingulate gyrus. Possibilities of therapeutic interventions are currently modest.

Numerous reports demonstrate both oxidative and nitrosative damage in the brains of AD patients (reviewed by Mangialasche et al. (2009)). This damage concerns lipids since 
numerous markers of lipid peroxidation (inter alia malondialdehyde, acrolein, 4-hydroxy-2nonenal and F2-isoprostanes) were found to be upregulated in brains of AD patients. Also markers of nucleic acid damage (like 8-hydroxydeoxyguanosine) or protein modification (like 3-nitrotyrosine (3-NT) or protein carbonyls) were upregulated.

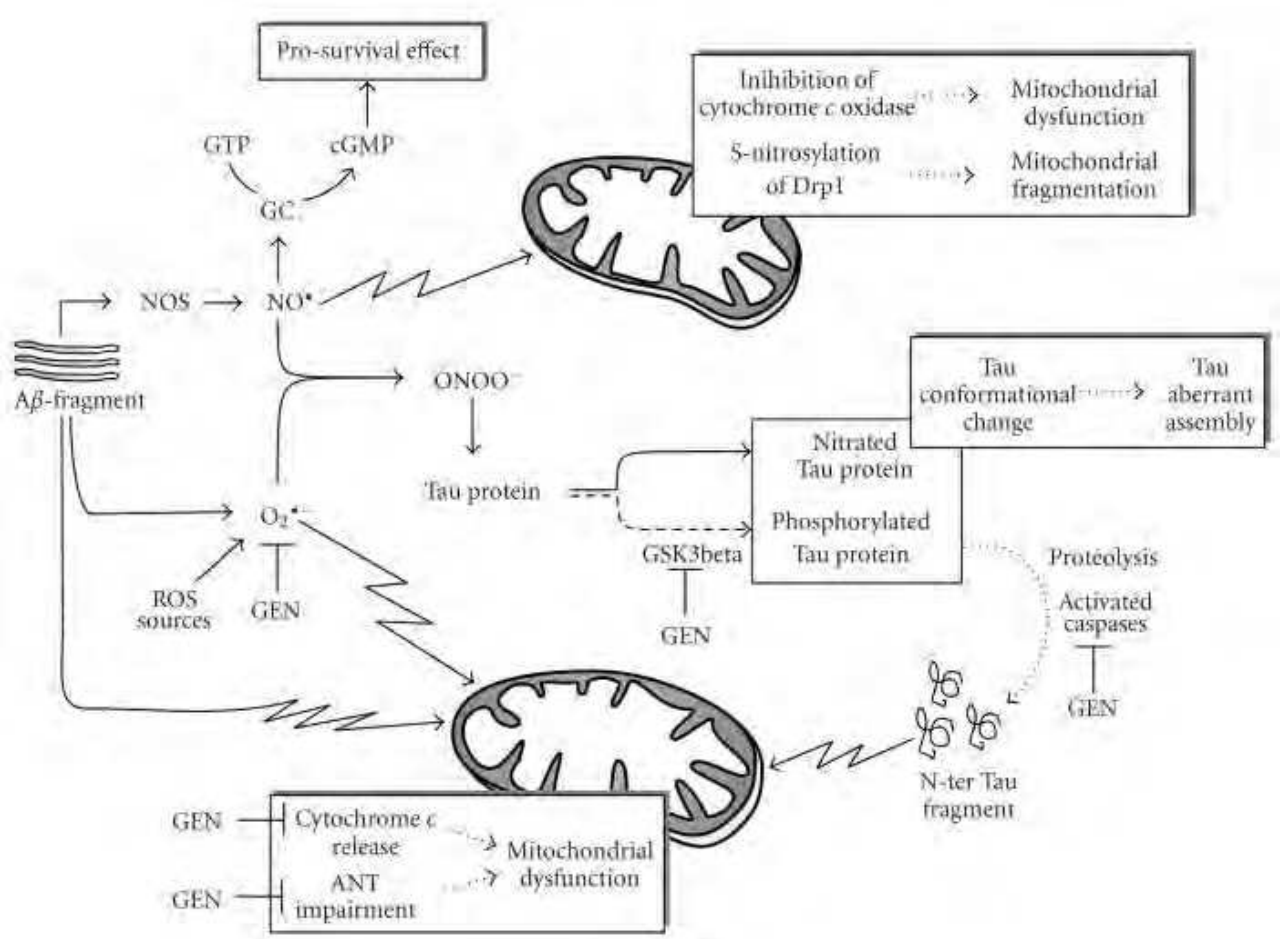

Fig. 4. Overview of the interplay between $A \beta$, Tau, oxidative/nitrosative stress, and mitochondria. Reproduced from Bobba et al. (2010). (C) Antonella Bobba et al., open access article.

Importantly, increased oxidative damage seems to be an early event in AD pathology since it is observed already in mildly cognitively impaired patients (Keller et al., 2005). This observations led to an idea of using various markers of oxidative/nitrosative damage as an early marker of AD pathology allowing to start therapeutical intervention in an early stage of the disease (see review by Galasko \& Montine (2010)). Currently, $\mathrm{F}_{2}$-isoprostane, a lipid peroxidation product, seems to be the most promising biomarker (de Leon et al., 2007; Pratico et al., 2002). Unfortunately while distinguishing AD and non-AD patients with markers measured in the cerebrospinal fluid seems to be pretty reliable there are some problems with applying these measures to plasma or urine samples. 
Results obtained in different animal models of AD are consistent with those observed in patients. Oxidative lipid damage seem to be an early event in transgenic mouse models of $\mathrm{AD}$ amyloidosis and in fact precede $\mathrm{A} \beta$ plaque formation (Pratico et al., 2001).

One simple explanation of increased nitrooxidative stress in AD is $\mathrm{A} \beta$ toxicity. This is in concert with $A \beta$ hypothesis that is currently the most popular one and assumes that formation of $\mathrm{A} \beta$ plaques is a central event in $\mathrm{AD}$ patophysiology. $\mathrm{A} \beta$ is thought to be capable of forming of free radicals by generation of hydrogen peroxide (Jomova et al., 2010). This potential of $A \beta$ to generate free radicals was confirmed by in vitro studies (Ill-Raga et al., 2010) and is connected with its affinity to redox metals (eg. copper and iron). From the other side in experimental models nitrooxidative stress precedes $A \beta$ plaques formation. There is also data showing that oxidative stress can actually alter metabolism of $A \beta$ precursor protein and tau and thus promote formation of plaques and tangles (Li et al., 2004; Lovell et al., 2004; Ohyagi et al., 2000).

An apparent hallmark of AD is decreased brain energy metabolism. Even when corrected for decreased number of neurons brain glucose metabolism is markedly decreased in AD patients (Heiss et al., 1991; Ogawa et al., 1996). This altered energetics may be attributed to mitochondrial dysfunction and promote production of ROS and RNS. Recent reports showed that it could be $A \beta$ that affects mitochondria and alters their functioning. $A \beta$ can access the mitochondrial matrix and accumulate in the mitochondria affecting activity of mitochondrial enzymes and potentiate release of ROS (Chen \& Yan, 2006).

Last but not least inflammatory processes seem to be a part of AD pathology - microglia are present in the $A \beta$ plaques and in their surroundings (Rozemuller et al., 2005; Schwab \& McGeer, 2008). Also A $\beta$ can in vitro activate microglia (Jekabsone et al., 2006). Activation of microglia is associated with production of ROS and potentially leads to damage of neighbouring neurons (Block et al., 2007).

\subsection{Nitrooxidative stress and Parkinson's disease}

Parkinson's disease (PD) is the second most common neurodegenerative disease. Disease progression starts with motor deficiencies - rigidity, shaking, slowness of movement and as progresses difficulties with gait and walking arise. In the advanced stages of the disease symptoms also include cognitive decline and behavioural changes. Pathologic hallmarks of $\mathrm{PD}$ are degeneration and death of dopaminergic neurons in substantia nigra and presence of Lewy bodies - intracellular aggregates of protein a-synuclein. Treatment includes stimulation of dopamine signalling, e.g. by supplementation with dopamine precursor - LDOPA or by administration of dopamine agonists (Lew, 2007).

Nitrooxidative stress is evident in the brains of PD patients. Increased levels of lipid peroxidation products: 4-hydroxy-2-nonenal and thiobarbituric acid reactive substances were found in substantia nigra of PD patients (Yoritaka et al., 1996). Also markers of oxidative damage to DNA and RNA like 8-hydroxyguanosine were found to be upregulated in this region (Zhang et al., 1999). Protein oxidation was found to be increased in PD, eg. levels of protein carbonyls were higher than in age-matched controls (Alam et al., 1997). 
Also data obtained from animal models of PD imply increased nitrooxidative stress. PINK1 and DJ-1 null mice had increased levels of oxidative stress markers (Andres-Mateos et al., 2007; Gautier et al., 2008). Toxicity of overexpressed a-synuclein in mice is also thought to be associated with free radicals (Masliah et al., 2000).

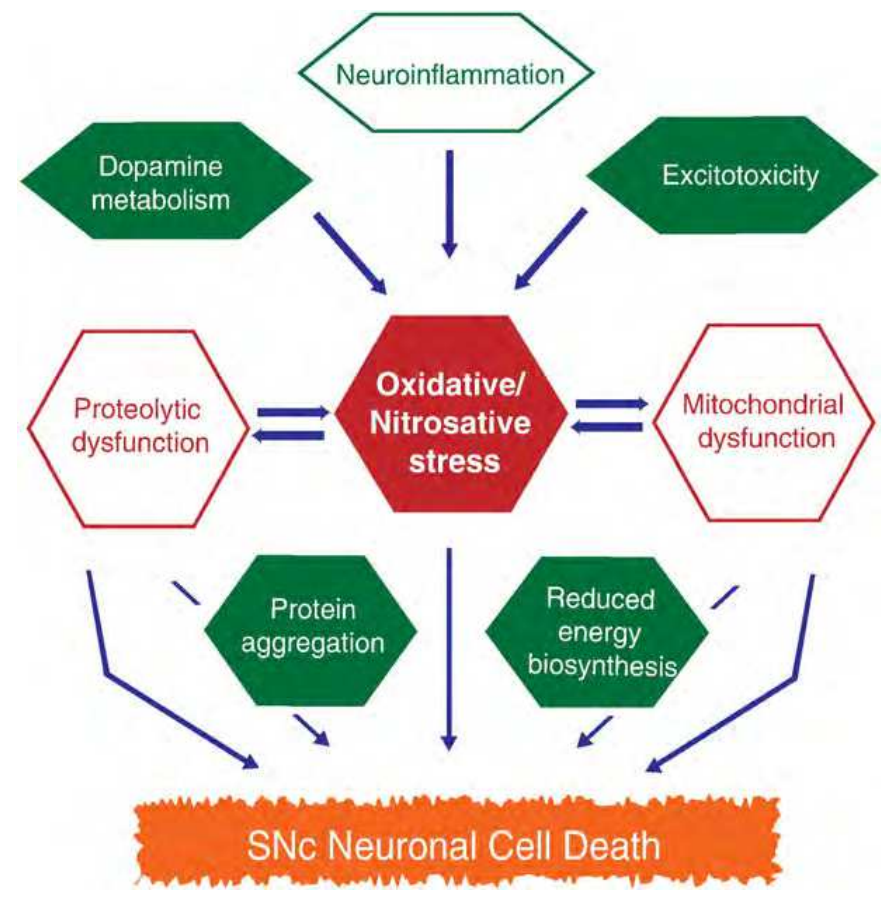

Fig. 5. Oxidative and nitrosative stress as a central event in PD pathology. SNc - substantia nigra compacta. Reproduced from Tsang \& Chung (2009). (c) Elsevier, with permission.

This upregulation of oxidative/nitrosative stress might be related to mitochondrial dysregulation observed in PD patients (see fig. 5). There is direct evidence showing decreased activity of mitochondrial complex I isolated from substantia nigra and frontal cortex of PD patients (Parker, Jr. et al., 2008; Schapira et al., 1990). Also increased oxidation of this protein complex has been shown in PD patients (Keeney et al., 2006). It seems that abnormalities in functioning of complex I lead to increased generation of ROS. Importantly, administration of several complex I inhibitors lead to PD symptoms: motor deficiencies and death of dopaminergic neurons. Accidental exposure to 1-methyl-4-phenyl-1,2,3,6tetrahydropyridine (MPTP, impurity in illegally synthesized recreational drug 1-methyl-4phenyl-4-propionoxypiperidine, MPPP) that is precursor of neurotoxic 1-methyl-4phenylpyridinium $\left(\mathrm{MPP}^{+}\right)$leads to a rapid development of irreversible parkinsonian symptoms (Langston et al., 1983). Due to its selectivity, MPTP administration to laboratory animals is widely used as a model of PD. On the other hand ROS and RNS might be involved in decrease of complex I activity especially by involvement of ONOO- (Navarro \& Boveris, 2009). 
Overstimulation of N-methyl-D-aspartate receptor (i.e. excitotoxicity) can be also involved in PD pathology. Resulting $\mathrm{Ca}^{2+}$ influx leads to activation of $\mathrm{NO}$ synthase and overproduction of $\mathrm{NO}$ that can react with $\mathrm{O}_{2}{ }^{-}$(overproduced due to mitochondrial dysregulation) and generate highly toxic ONOO-. This mechanism seems to work in mice treated with MPTP since various NO synthase knockout mice were resistant to MPTP toxicity (Liberatore et al., 1999; Przedborski et al., 1996).

Activation of microglia is also present in PD pathology. Such activation was observed in PD patients in vivo by PET imaging (Gerhard et al., 2006). It was also noted in the brains of MPTP-intoxicated patients (Langston et al., 1999) and in animals that received MPTP in order to induce PD symptoms (Czlonkowska et al., 1996; Kohutnicka et al., 1998). One link between this persistent activation of microglia and pathology is increased production of ROS/RNS.

\subsection{Nitrooxidative stress and glaucoma}

Glaucoma - neurodegenerative disease of the retina - is the most common cause of irreversible blindness worldwide (Resnikoff et al., 2004). Progression of glaucoma is associated with gradual narrowing of visual field, typically starting from the periphery. It is sometimes called 'a sneaky theft of sight' since progression of the disease may remain unnoticed for many years. Pathological changes in glaucoma concern retinal ganglion cells and its axons that build optic nerve (Foster et al., 2002). Some recent data point that glaucoma is not limited to retina and optic nerve but also affect upstream components of the visual pathway (Gupta \& Yucel, 2007). Current treatment strategies concentrate on lowering intraocular pressure (IOP), a condition observed in most but not all of the cases of glaucoma.

Measuring nitrooxidative damage biomarkers is a bit easier in case of glaucoma as aqueous humor and vitreous humor are pretty easily accessible. MDA level was two times higher in aqueous humor obtained from patients with open angle glaucoma than from healthy controls (Ghanem et al., 2010; Yildirim et al., 2005). Also open angle glaucoma patients had higher level of oxidative DNA damages in cells of trabecular meshwork (structure engaged in control of IOP). Importantly these alterations correlated well with IOP and narrowing of visual field (Izzotti et al., 2003; Sacca et al., 2005). Glutathione, ascorbic acid and tyrosine low molecular antioxidants were downregulated in glaucoma patients (Ferreira et al., 2004), whereas SOD activity was diminished.

Also in animal models of glaucoma markers of oxidative/nitrosative stress were upregulated. MDA was upregulated in a model of high-pressure glaucoma (Moreno et al., 2004). Also carbonyl groups in retinas from these animals were upregulated. SOD activity in a model of high-pressure glaucoma was diminished (Moreno et al., 2004).

Signs of mitochondrial dysregulation were also noted in glaucoma patients. Abu-Amero et al. (2006) revealed association between primary open-angle glaucoma and changes in mitochondrial DNA. They also found that mitochndrial respiratory activity was significantly decreased in these patients. In normal tension glaucoma mutations in genes coding mitochondrial proteins were found (Mabuchi et al., 2007; Wolf et al., 2009). 


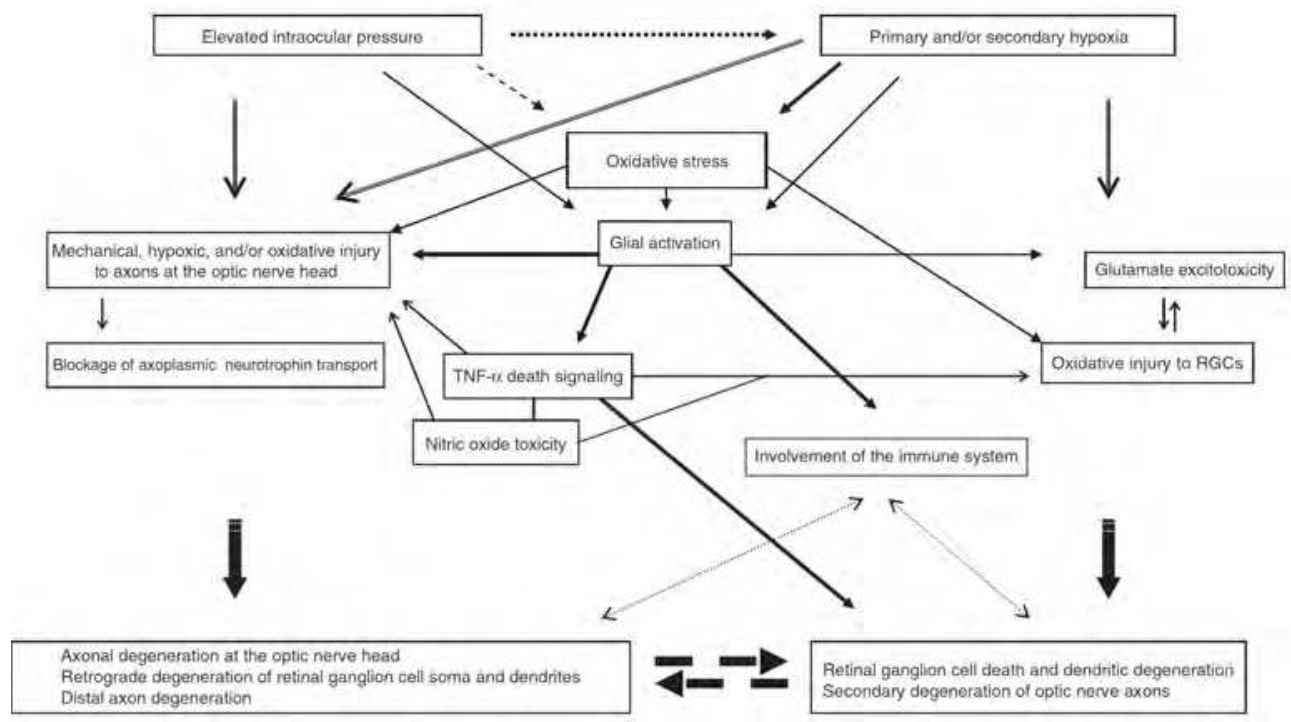

Fig. 6. Multiple proposed pathogenic mechanisms in glaucoma seem to related to oxidative stress as a common pathway. Reproduced from Tezel (2006). (C) Elsevier, with permission.

It is well known that glutamate administered into vitreous humor is toxic for retinal ganglion cells (Lucas \& Newhouse, 1957; Quigley, 1999). Also N-methyl-D-aspartate intravitreous administration causes massive retinal ganglion cell loss (Nakazawa et al., 2005). The ability of glial cells to buffer extracellular glutamate might be impaired (Martin et al., 2002; Moreno et al., 2005). Although, some earlier reports demonstrated elevated glutamate in glaucoma patients and in some glaucoma models (Brooks et al., 1997; Dkhissi et al., 1999; Dreyer et al., 1996), other groups did not observe glutamate elevation in similar settings (Carter-Dawson et al., 2002; Honkanen et al., 2003).

Immune component is also present in glaucoma (Tezel, 2011). Upregulation of different components of immune system was found in glaucoma patients (Kuehn et al., 2006; Wax et al., 1998; Yang, 2004). Also in various animal models immune response was upregulated (Johnson et al., 2007; Steele et al., 2006). So called 'para-inflammation' - weak but persistent activation of immune system seem to be the case in glaucoma. Oxidized macromolecules stimulate resident immune cells including microglia and seem to stimulate parainflammation (Xu et al., 2009).

\section{Antioxidant therapies in neurodegenerative diseases: Rationales and precautions}

As shown above, ROS and RNS could be regarded as 'key players' in pathologies of various neurodegenerative diseases. This leads to idea that antioxidant supplementation can be a reasonable therapeutic strategy in neurodegenerative disorders. One can imagine two major strategies to reduce nitrooxidative stress in these pathologic conditions (Uttara et al., 2009): 
- 'upstream' to nitroxidative stress

- 'downstream' to nitrooxidative stress

'Upstream' antioxidant therapies would lead to reduction of ROS/RNS production. This could be achieved by chelating metals that catalyze generation of free radicals (like hydroxyl radical), inhibition of enzymatic reactions leading to generation of ROS/RNS or its precursors (e.g. hydrogen peroxide or nitric oxide). 'Downstream' antioxidant therapies would include agents reducing or preventing inflammation but also direct antioxidants, i.e. 'antioxidants' in traditional and narrow meaning. Some examples of antioxidants are listed in table 1.

\begin{tabular}{|c|c|c|}
\hline & Mechanism of action & Examples \\
\hline $\begin{array}{l}\text { Upstream } \\
\text { antioxidants }\end{array}$ & $\begin{array}{l}\text { Preventing formation of free } \\
\text { radicals }\end{array}$ & 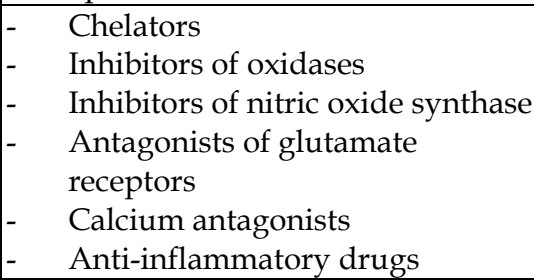 \\
\hline \multirow{3}{*}{$\begin{array}{l}\text { Downstream } \\
\text { antioxidants }\end{array}$} & $\begin{array}{l}\text { Scavenging free radicals (direct } \\
\text { antioxidants) }\end{array}$ & \begin{tabular}{|ll}
- & Tocopherols \\
- & Flavonoids \\
- & Selenium-containigs compounds \\
(e.g. ebselen) \\
-
\end{tabular} \\
\hline & $\begin{array}{l}\text { Catalizing decomposition of free } \\
\text { radicals }\end{array}$ & $\begin{array}{l}\text { Mimetics of superoxide } \\
\text { dismutase and/or catalase } \\
\text { (e.g. tempol) }\end{array}$ \\
\hline & $\begin{array}{l}\text { Preventing secondary burden by } \\
\text { ROS/RNS }\end{array}$ & $\begin{array}{ll}- & \text { Creatine } \\
- & \text { Carnitine } \\
- & \text { Lipoic acid } \\
- & \text { Nicotinamide } \\
- & \text { N-butyl-a-phenylnitrone }\end{array}$ \\
\hline
\end{tabular}

Table 1. Examples of upstream and downstream antioxidants.

Many of the known antioxidants were tested in various animal models of neurodegenerative diseases and some of them were also tested in clinical trials (see reviews by (Moosmann \& Behl, 2002; Tan et al., 2003; Uttara et al., 2009)). It is hard to summarize this data but one has to admit that outcomes are somehow disappointing. Theoretically, the best we can expect in case of antioxidant therapy in neurodegenerative diseases is cessation of degenerative processes. This means that we can count on stopping the process that is normally already pretty advanced, in many diseases the first symptoms appear only when $40-50 \%$ of cells are lost.

Another lesson from these numerous studies concerns features which should characterize an antioxidant that could be potentially protective in neurodegenerative diseases. Ability to cross the brain-blood barrier (BBB) seems to be the crucial one (Gilgun-Sherki et al., 2001). 
Many of the known antioxidants have poor ability to cross BBB. The way the molecule crosses BBB can be also of importance, e.g. vitamin $C$ is transported as its oxidised form, dehydroascorbic acid, by glucose transporter and then reduced back to ascorbic acid. However, reducing dehydroascorbic acid consumes glutathione. This means that vitamin $\mathrm{C}$ supplementation would not lead to increase in the net cerebral antioxidant capacity (Tan et al., 2003).

There are some issues and controversies concerning antioxidant therapies per se. For years antioxidants used to be shown unequivocally as safe and widely applicable drugs. However, recent clinical trials suggest more careful approach to antioxidant application. In some cases they can even potentiate the damage (Halliwell, 2000; Salganik, 2001). One of the many possible reasons is that ROS and RNS are not only damaging agents but as mentioned before also play a vital signalling role in the cell. Cells and organisms maintain redox homeostasis and too low levels of ROS and RNS can also be detrimental. Potential sideeffects of antioxidants are summarised in fig. 7.

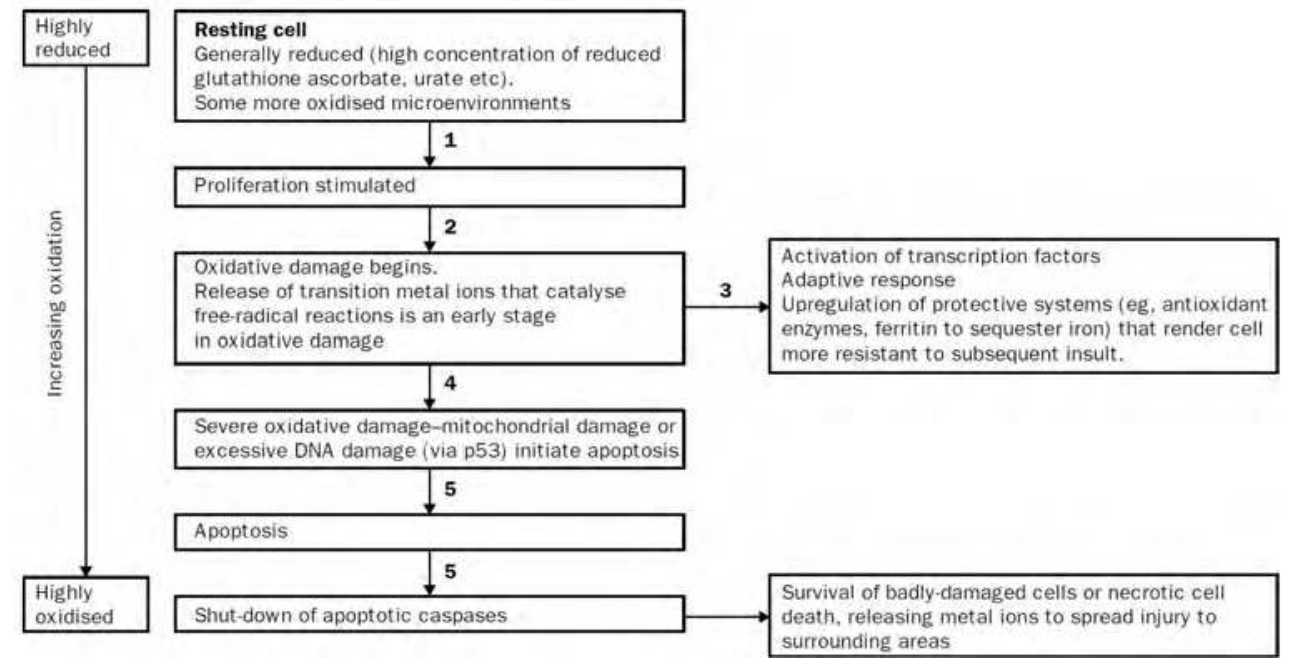

Fig. 7. Potential side-effects of antioxidants. Antioxidants might: (1) inhibit cell proliferation by preventing transient oxidations that stimulate protein phosphorylation and transcription factors; (2) protect against oxidative damage by scavenging excess ROS/RNS; (3) prevent adaptation to oxidative damage by decreasing transcription-factor activation; (4) accelerate oxidative damage by reducing transition-metal ions into their lower oxidation states that are better promoters of free-radical damage; and (5) inhibit free-radical-induced apoptosis, either beneficial to the organism or deleterious. Reproduced from Halliwell (2000).

(c) Elsevier, with permission.

Good examples illustrating are mimetics of SOD, e.g. TEMPOL and other nitroxides, stable radicals that convert superoxide radical to hydrogen peroxide. Administration of substances that would help in eliminating superoxide radical seems to be a good therapeutic strategy and proved to be effective in many settings (Wilcox, 2010). On the other hand deleterious effects of SOD overexpression are well known, as they have been demonstrated in many 
settings including cell lines (Groner et al., 1986) and transgenic animals (Avraham et al., 1988; Ceballos-Picot et al., 1991). Increased oxidative stress in Down's syndrome seems to be associated with SOD-1 overexpression (Sinet, 1982). Dose-dependency curve for SOD and also its mimetics in different experimental settings is 'bell-shaped', i.e. after reaching maximum protective effect further increasing the dose leads to decreasing the protective effect (McCord, 2008).

\section{Conclusions}

Nitrooxidative stress seems to be not only a common phenomenon in various neurodegenerative disorders, but also a common mechanism of neurodegeneration. Obviously, there are 'disease-specific' factors that activate and inter-play with nitrooxidative stress but neurodegenerative diseases seem to share some factors that are 'key players' in their pathology: excitotoxicity, mitochondrial disruption and neuroinflammation.

Antioxidant supplementation seemed to be an excellent therapeutic and prophylactic strategy for various neurodegenerative disorders. Recently, antioxidant supplementation occurred not as safe as we previously thought. Also efficacy of these therapies is somehow controversial. Perhaps we need antioxidants that are precisely 'targeted' and evaluate accurate dosing of these substances.

\section{References}

Abello, N.; Kerstjens, H.A.; Postma, D.S. \& Bischoff, R. (2009). Protein tyrosine nitration: selectivity, physicochemical and biological consequences, denitration, and proteomics methods for the identification of tyrosine-nitrated proteins. J Proteome Res , Vol. 8, No. 7, (2009), pp. 3222-3238, ISSN 1535-3893

Abu-Amero, K.K.; Morales, J. \& Bosley, T.M. (2006). Mitochondrial abnormalities in patients with primary open-angle glaucoma. Invest Ophthalmol Vis Sci , Vol. 47, No. 6, (2006), pp. 2533-2541, ISSN 0146-0404

Alam, Z.I.; Daniel, S.E.; Lees, A.J.; Marsden, D.C.; Jenner, P. \& Halliwell, B. (1997). A generalised increase in protein carbonyls in the brain in Parkinson's but not incidental Lewy body disease. J Neurochem , Vol. 69, No. 3, (1997), pp. 1326-1329, ISSN 0022-3042

Andres-Mateos, E.; Perier, C.; Zhang, L.; Blanchard-Fillion, B.; Greco, T.M.; Thomas, B.; Ko, H.S.; Sasaki, M.; Ischiropoulos, H.; Przedborski, S.; Dawson, T.M. \& Dawson, V.L. (2007). DJ-1 gene deletion reveals that DJ-1 is an atypical peroxiredoxin-like peroxidase. Proc Natl Acad Sci U S A , Vol. 104, No. 37, (2007), pp. 14807-14812, ISSN 0027-8424

Ascenzi, P.; di, M.A.; Sciorati, C. \& Clementi, E. (2010). Peroxynitrite-An ugly biofactor? Biofactors, Vol. 36, No. 4, (2010), pp. 264-273, ISSN 0951-6433

Avraham, K.B.; Schickler, M.; Sapoznikov, D.; Yarom, R. \& Groner, Y. (1988). Down's syndrome: abnormal neuromuscular junction in tongue of transgenic mice with elevated levels of human $\mathrm{Cu} / \mathrm{Zn}$-superoxide dismutase. Cell , Vol. 54, No. 6, (1988), pp. 823-829, ISSN 0092-8674

Benov, L. (2001). How superoxide radical damages the cell. Protoplasma, Vol. 217, No. 1-3, (2001), pp. 33-36, ISSN 0033-183X 
Block, M.L.; Zecca, L. \& Hong, J.S. (2007). Microglia-mediated neurotoxicity: uncovering the molecular mechanisms. Nat Rev Neurosci , Vol. 8, No. 1, (2007), pp. 57-69, ISSN 1471-003X

Bobba, A.; Petragallo, V.A.; Marra, E. \& Atlante, A. (2010). Alzheimer's proteins, oxidative stress, and mitochondrial dysfunction interplay in a neuronal model of Alzheimer's disease. Int J Alzheimers Dis , Vol. 2010. pii: 621870., No. (2010), pp. 621870-, ISSN 2090-0252

Brenneisen, P.; Steinbrenner, H. \& Sies, H. (2005). Selenium, oxidative stress, and health aspects. Mol Aspects Med, Vol. 26, No. 4-5, (2005), pp. 256-267, ISSN 0098-2997

Brooks, D.E.; Garcia, G.A.; Dreyer, E.B.; Zurakowski, D. \& Franco-Bourland, R.E. (1997). Vitreous body glutamate concentration in dogs with glaucoma. Am J Vet Res, Vol. 58, No. 8, (1997), pp. 864-867, ISSN

Buonocore, G.; Perrone, S. \& Tataranno, M.L. (2010). Oxygen toxicity: chemistry and biology of reactive oxygen species. Semin Fetal Neonatal Med, Vol. 15, No. 4, (2010), pp. 186-190, ISSN 1744-165X

Carter-Dawson, L.; Crawford, M.L.; Harwerth, R.S.; Smith, E.L., III; Feldman, R.; Shen, F.F.; Mitchell, C.K. \& Whitetree, A. (2002). Vitreal glutamate concentration in monkeys with experimental glaucoma. Invest Ophthalmol Vis Sci , Vol. 43, No. 8, (2002), pp. 2633-2637, ISSN

Catala, A. (2010). A synopsis of the process of lipid peroxidation since the discovery of the essential fatty acids. Biochem Biophys Res Commun, Vol. 399, No. 3, (2010), pp. 318-323, ISSN 0006-291X

Ceballos-Picot, I.; Nicole, A.; Briand, P.; Grimber, G.; Delacourte, A.; Defossez, A.; JavoyAgid, F.; Lafon, M.; Blouin, J.L. \& Sinet, P.M. (1991). Neuronal-specific expression of human copper-zinc superoxide dismutase gene in transgenic mice: animal model of gene dosage effects in Down's syndrome. Brain Res, Vol. 552, No. 2, (1991), pp. 198-214, ISSN 0006-8993

Chance, B.; Sies, H. \& Boveris, A. (1979). Hydroperoxide metabolism in mammalian organs. Physiol Rev , Vol. 59, No. 3, (1979), pp. 527-605, ISSN 0031-9333

Chen, X. \& Yan, S.D. (2006). Mitochondrial Abeta: a potential cause of metabolic dysfunction in Alzheimer's disease. IUBMB Life, Vol. 58, No. 12, (2006), pp. 686-694, ISSN 15216543

Cheng, F.C.; Jen, J.F. \& Tsai, T.H. (2002). Hydroxyl radical in living systems and its separation methods. J Chromatogr B Analyt Technol Biomed Life Sci , Vol. 781, No. 1-2, (2002), pp. 481-496, ISSN 1570-0232

Clement, M.V. \& Pervaiz, S. (1999). Reactive oxygen intermediates regulate cellular response to apoptotic stimuli: an hypothesis. Free Radic Res , Vol. 30, No. 4, (1999), pp. 247252, ISSN 1071-5762

Commoner, B.; Townsend, J. \& Pake, G.E. (1954). Free radicals in biological materials. Nature, Vol. 174, No. 4432, (1954), pp. 689-691, ISSN 0028-0836

Czlonkowska, A.; Kohutnicka, M.; Kurkowska-Jastrzebska, I. \& Czlonkowski, A. (1996). Microglial reaction in MPTP (1-methyl-4-phenyl-1,2,3,6-tetrahydropyridine) induced Parkinson's disease mice model. Neurodegeneration , Vol. 5, No. 2, (1996), pp. 137-143, ISSN 1055-8330

de Leon, M.J.; Mosconi, L.; Li, J.; De, S.S.; Yao, Y.; Tsui, W.H.; Pirraglia, E.; Rich, K.; Javier, E.; Brys, M.; Glodzik, L.; Switalski, R.; Saint Louis, L.A. \& Pratico, D. (2007). 
Longitudinal CSF isoprostane and MRI atrophy in the progression to AD. J Neurol, Vol. 254, No. 12, (2007), pp. 1666-1675, ISSN 0340-5354

Dkhissi, O.; Chanut, E.; Wasowicz, M.; Savoldelli, M.; Nguyen-Legros, J.; Minvielle, F. \& Versaux-Botteri, C. (1999). Retinal TUNEL-positive cells and high glutamate levels in vitreous humor of mutant quail with a glaucoma-like disorder. Invest Ophthalmol Vis Sci , Vol. 40, No. 5, (1999), pp. 990-995, ISSN

Donald, K.W. (1947). Oxygen poisoning in man; signs and symptoms of oxygen poisoning. Br Med J , Vol. 1, No. 4507, (1947), pp. 712-717, ISSN 0007-1447

Dreyer, E.B.; Zurakowski, D.; Schumer, R.A.; Podos, S.M. \& Lipton, S.A. (1996). Elevated glutamate levels in the vitreous body of humans and monkeys with glaucoma. Arch Ophthalmol , Vol. 114, No. 3, (1996), pp. 299-305, ISSN 0003-9950

Enciclopedia Britannica (2011). Hooke's law, 01.10.2011, Available from http://www.britannica.com/EBchecked/topic/271336/Hookes-law

Faraci, F.M. \& Didion, S.P. (2004). Vascular protection: superoxide dismutase isoforms in the vessel wall. Arterioscler Thromb Vasc Biol , Vol. 24, No. 8, (2004), pp. 1367-1373, ISSN 1079-5642

Ferreira, S.M.; Lerner, S.F.; Brunzini, R.; Evelson, P.A. \& Llesuy, S.F. (2004). Oxidative stress markers in aqueous humor of glaucoma patients. Am J Ophthalmol , Vol. 137, No. 1, (2004), pp. 62-69, ISSN 0002-9394

Foster, P.J.; Buhrmann, R.; Quigley, H.A. \& Johnson, G.J. (2002). The definition and classification of glaucoma in prevalence surveys. Br J Ophthalmol , Vol. 86, No. 2, (2002), pp. 238-242, ISSN 0007-1161

Fridovich, I. (1975). Oxygen: boon and bane. Am Sci , Vol. 63, No. 1, (1975), pp. 54-59, ISSN 0003-0996

Fridovich, I. (1983). Superoxide radical: an endogenous toxicant. Annu Rev Pharmacol Toxicol , Vol. 23, No. (1983), pp. 239-257, ISSN 0362-1642

Galasko, D. \& Montine, T.J. (2010). Biomarkers of oxidative damage and inflammation in Alzheimer's disease. Biomark Med , Vol. 4, No. 1, (2010), pp. 27-36, ISSN 1752-0363

Gautier, C.A.; Kitada, T. \& Shen, J. (2008). Loss of PINK1 causes mitochondrial functional defects and increased sensitivity to oxidative stress. Proc Natl Acad Sci U S A, Vol. 105, No. 32, (2008), pp. 11364-11369, ISSN 0027-8424

Gerhard, A.; Pavese, N.; Hotton, G.; Turkheimer, F.; Es, M.; Hammers, A.; Eggert, K.; Oertel, W.; Banati, R.B. \& Brooks, D.J. (2006). In vivo imaging of microglial activation with [11C](R)-PK11195 PET in idiopathic Parkinson's disease. Neurobiol Dis , Vol. 21, No. 2, (2006), pp. 404-412, ISSN 0969-9961

Gerschman, R.; Gilbert, D.L.; Nye, S.W.; Dwyer, P. \& Fenn, W.O. (1954). Oxygen poisoning and x-irradiation: a mechanism in common. Science, Vol. 119, No. 3097, (1954), pp. 623-626, ISSN 0036-8075

Ghanem, A.A.; Arafa, L.F. \& El Baz, A. (2010). Oxidative stress markers in patients with primary open-angle glaucoma. Curr Eye Res , Vol. 35, No. 4, (2010), pp. 295-301, ISSN 0271-3683

Gilgun-Sherki, Y.; Melamed, E. \& Offen, D. (2001). Oxidative stress inducedneurodegenerative diseases: the need for antioxidants that penetrate the blood brain barrier. Neuropharmacology , Vol. 40, No. 8, (2001), pp. 959-975, ISSN 00283908 
Giorgio, M.; Trinei, M.; Migliaccio, E. \& Pelicci, P.G. (2007). Hydrogen peroxide: a metabolic by-product or a common mediator of ageing signals? Nat Rev Mol Cell Biol , Vol. 8, No. 9, (2007), pp. 722-728, ISSN 1471-0072

Golden, T.R. \& Patel, M. (2009). Catalytic antioxidants and neurodegeneration. Antioxid Redox Signal , Vol. 11, No. 3, (2009), pp. 555-570, ISSN 1523-0864

Groner, Y.; Elroy-Stein, O.; Bernstein, Y.; Dafni, N.; Levanon, D.; Danciger, E. \& Neer, A. (1986). Molecular genetics of Down's syndrome: overexpression of transfected human $\mathrm{Cu} / \mathrm{Zn}$-superoxide dismutase gene and the consequent physiological changes. Cold Spring Harb Symp Quant Biol , Vol. 51 Pt 1:381-93., No. (1986), pp. 381-393, ISSN 0091-7451

Gupta, N. \& Yucel, Y.H. (2007). What changes can we expect in the brain of glaucoma patients? Surv Ophthalmol , Vol. 52 Suppl 2:S122-6., No. (2007), pp. S122-S126, ISSN 0039-6257

Halliwell, B. (2000). The antioxidant paradox. Lancet, Vol. 355, No. 9210, (2000), pp. 11791180, ISSN 0140-6736

Halliwell, B. (2009). The wanderings of a free radical. Free Radic Biol Med , Vol. 46, No. 5, (2009), pp. 531-542, ISSN 0891-5849

Halliwell, B. \& Gutteridge, J.M. (1984). Oxygen toxicity, oxygen radicals, transition metals and disease. Biochem J , Vol. 219, No. 1, (1984), pp. 1-14, ISSN 0264-6021

Hampton, M.B. \& Orrenius, S. (1998). Redox regulation of apoptotic cell death. Biofactors, Vol. 8, No. 1-2, (1998), pp. 1-5, ISSN 0951-6433

Heiss, W.D.; Szelies, B.; Kessler, J. \& Herholz, K. (1991). Abnormalities of energy metabolism in Alzheimer's disease studied with PET. Ann N Y Acad Sci , Vol. 640:65-71., No. (1991), pp. 65-71, ISSN 0077-8923

Henderson, N. (2000). The Discovery of Organic Free Radicals by Moses Gomberg, 24.10.2011, Available from http://portal.acs.org/portal/acs/corg/content?_nfpb=true\&_pageLabel=PP_ARTI CLEMAIN\&node_id=924\&content_id=WPCP_007609\&use_sec=true\&sec_url_var= region1\&_uuid=2010c927-eb9f-41c8-89b1-ff0c459381c7

Honkanen, R.A.; Baruah, S.; Zimmerman, M.B.; Khanna, C.L.; Weaver, Y.K.; Narkiewicz, J.; Waziri, R.; Gehrs, K.M.; Weingeist, T.A.; Boldt, H.C.; Folk, J.C.; Russell, S.R. \& Kwon, Y.H. (2003). Vitreous amino acid concentrations in patients with glaucoma undergoing vitrectomy. Arch Ophthalmol , Vol. 121, No. 2, (2003), pp. 183-188, ISSN 0003-9950

Huang, T.T.; Carlson, E.J.; Kozy, H.M.; Mantha, S.; Goodman, S.I.; Ursell, P.C. \& Epstein, C.J. (2001). Genetic modification of prenatal lethality and dilated cardiomyopathy in Mn superoxide dismutase mutant mice. Free Radic Biol Med , Vol. 31, No. 9, (2001), pp. 1101-1110, ISSN 0891-5849

Ill-Raga, G.; Ramos-Fernandez, E.; Guix, F.X.; Tajes, M.; Bosch-Morato, M.; Palomer, E.; Godoy, J.; Belmar, S.; Cerpa, W.; Simpkins, J.W.; Inestrosa And NC \& Munoz, F.J. (2010). Amyloid-beta peptide fibrils induce nitro-oxidative stress in neuronal cells. J Alzheimers Dis , Vol. 22, No. 2, (2010), pp. 641-652, ISSN 1387-2877

Inkret, W.C.; Meinhold, C.B. \& Taschner, J.C. (1995). A brief history of radiation protection standards. Los Alamos Science , Vol. 23, No. (1995), pp. 116-123, ISSN 0273-7116 
Ischiropoulos, H. \& Beckman, J.S. (2003). Oxidative stress and nitration in neurodegeneration: cause, effect, or association? J Clin Invest, Vol. 111, No. 2, (2003), pp. 163-169, ISSN 0021-9738

IUPAC (2005). Nomenclature of Inorganic Chemistry. IUPAC Recommendations 2005. RSC Publishing - IUPAC, ISBN 0-85404-438-8, Cambridge

Izzotti, A.; Sacca, S.C.; Cartiglia, C. \& De Flora, S. (2003). Oxidative deoxyribonucleic acid damage in the eyes of glaucoma patients. Am J Med, Vol. 114, No. 8, (2003), pp. 638-646, ISSN 0002-9343

Jekabsone, A.; Mander, P.K.; Tickler, A.; Sharpe, M. \& Brown, G.C. (2006). Fibrillar betaamyloid peptide Abeta1-40 activates microglial proliferation via stimulating TNFalpha release and $\mathrm{H} 2 \mathrm{O} 2$ derived from NADPH oxidase: a cell culture study. J Neuroinflammation, Vol. 3:24., No. (2006), pp. 24-, ISSN 1742-2094

Johnson, E.C.; Jia, L.; Cepurna, W.O.; Doser, T.A. \& Morrison, J.C. (2007). Global changes in optic nerve head gene expression after exposure to elevated intraocular pressure in a rat glaucoma model. Invest Ophthalmol Vis Sci , Vol. 48, No. 7, (2007), pp. 31613177, ISSN 0146-0404

Jomova, K.; Vondrakova, D.; Lawson, M. \& Valko, M. (2010). Metals, oxidative stress and neurodegenerative disorders. Mol Cell Biochem, Vol. 345, No. 1-2, (2010), pp. 91104, ISSN 0300-8177

Kagan, V.E.; Bayir, H.A.; Belikova, N.A.; Kapralov, O.; Tyurina, Y.Y.; Tyurin, V.A.; Jiang, J.; Stoyanovsky, D.A.; Wipf, P.; Kochanek, P.M.; Greenberger, J.S.; Pitt, B.; Shvedova, A.A. \& Borisenko, G. (2009). Cytochrome c/cardiolipin relations in mitochondria: a kiss of death. Free Radic Biol Med, Vol. 46, No. 11, (2009), pp. 1439-1453, ISSN 0891-5849

Keeney, P.M.; Xie, J.; Capaldi, R.A. \& Bennett, J.P., Jr. (2006). Parkinson's disease brain mitochondrial complex I has oxidatively damaged subunits and is functionally impaired and misassembled. J Neurosci , Vol. 26, No. 19, (2006), pp. 5256-5264, ISSN

Keller, J.N.; Schmitt, F.A.; Scheff, S.W.; Ding, Q.; Chen, Q.; Butterfield, D.A. \& Markesbery, W.R. (2005). Evidence of increased oxidative damage in subjects with mild cognitive impairment. Neurology , Vol. 64, No. 7, (2005), pp. 1152-1156, ISSN 00283878

Klotz, L.O.; Schroeder, P. \& Sies, H. (2002). Peroxynitrite signaling: receptor tyrosine kinases and activation of stress-responsive pathways. Free Radic Biol Med, Vol. 33, No. 6, (2002), pp. 737-743, ISSN 0891-5849

Kohutnicka, M.; Lewandowska, E.; Kurkowska-Jastrzebska, I.; Czlonkowski, A. \& Czlonkowska, A. (1998). Microglial and astrocytic involvement in a murine model of Parkinson's disease induced by 1-methyl-4-phenyl-1,2,3,6-tetrahydropyridine (MPTP). Immunopharmacology , Vol. 39, No. 3, (1998), pp. 167-180, ISSN 0162-3109

Kuehn, M.H.; Kim, C.Y.; Ostojic, J.; Bellin, M.; Alward, W.L.; Stone, E.M.; Sakaguchi, D.S.; Grozdanic, S.D. \& Kwon, Y.H. (2006). Retinal synthesis and deposition of complement components induced by ocular hypertension. Exp Eye Res, Vol. 83, No. 3, (2006), pp. 620-628, ISSN 0014-4835

Langston, J.W.; Ballard, P.; Tetrud, J.W. \& Irwin, I. (1983). Chronic Parkinsonism in humans due to a product of meperidine-analog synthesis. Science , Vol. 219, No. 4587, (1983), pp. 979-980, ISSN 0036-8075 
Langston, J.W.; Forno, L.S.; Tetrud, J.; Reeves, A.G.; Kaplan, J.A. \& Karluk, D. (1999). Evidence of active nerve cell degeneration in the substantia nigra of humans years after 1-methyl-4-phenyl-1,2,3,6-tetrahydropyridine exposure. Ann Neurol , Vol. 46, No. 4, (1999), pp. 598-605, ISSN 0364-5134

Lew, M. (2007). Overview of Parkinson's disease. Pharmacotherapy , Vol. 27, No. 12 Pt 2, (2007), pp. 155S-160S, ISSN 0277-0008

Li, F.; Calingasan, N.Y.; Yu, F.; Mauck, W.M.; Toidze, M.; Almeida, C.G.; Takahashi, R.H.; Carlson, G.A.; Flint, B.M.; Lin, M.T. \& Gouras, G.K. (2004). Increased plaque burden in brains of APP mutant MnSOD heterozygous knockout mice. J Neurochem, Vol. 89, No. 5, (2004), pp. 1308-1312, ISSN 0022-3042

Liberatore, G.T.; Jackson-Lewis, V.; Vukosavic, S.; Mandir, A.S.; Vila, M.; McAuliffe, W.G.; Dawson, V.L.; Dawson, T.M. \& Przedborski, S. (1999). Inducible nitric oxide synthase stimulates dopaminergic neurodegeneration in the MPTP model of Parkinson disease. Nat Med, Vol. 5, No. 12, (1999), pp. 1403-1409, ISSN 1078-8956

Lovell, M.A.; Xiong, S.; Xie, C.; Davies, P. \& Markesbery, W.R. (2004). Induction of hyperphosphorylated tau in primary rat cortical neuron cultures mediated by oxidative stress and glycogen synthase kinase-3. J Alzheimers Dis , Vol. 6, No. 6, (2004), pp. 659-671, ISSN 1387-2877

Lucas, D.R. \& Newhouse, J.P. (1957). The toxic effect of sodium L-glutamate on the inner layers of the retina. AMA Arch Ophthalmol , Vol. 58, No. 2, (1957), pp. 193-201, ISSN

Mabuchi, F.; Tang, S.; Kashiwagi, K.; Yamagata, Z.; Iijima, H. \& Tsukahara, S. (2007). The OPA1 gene polymorphism is associated with normal tension and high tension glaucoma. Am J Ophthalmol , Vol. 143, No. 1, (2007), pp. 125-130, ISSN 0002-9394

Mangialasche, F.; Polidori, M.C.; Monastero, R.; Ercolani, S.; Camarda, C.; Cecchetti, R. \& Mecocci, P. (2009). Biomarkers of oxidative and nitrosative damage in Alzheimer's disease and mild cognitive impairment. Ageing Res Rev , Vol. 8, No. 4, (2009), pp. 285-305, ISSN 1568-1637

Martin, K.R.; Levkovitch-Verbin, H.; Valenta, D.; Baumrind, L.; Pease, M.E. \& Quigley, H.A. (2002). Retinal glutamate transporter changes in experimental glaucoma and after optic nerve transection in the rat. Invest Ophthalmol Vis Sci , Vol. 43, No. 7, (2002), pp. 2236-2243, ISSN 0146-0404

Masliah, E.; Rockenstein, E.; Veinbergs, I.; Mallory, M.; Hashimoto, M.; Takeda, A.; Sagara, Y.; Sisk, A. \& Mucke, L. (2000). Dopaminergic loss and inclusion body formation in alpha-synuclein mice: implications for neurodegenerative disorders. Science, Vol. 287, No. 5456, (2000), pp. 1265-1269, ISSN 0036-8075

McCord, J.M. (2000). The evolution of free radicals and oxidative stress. Am J Med , Vol. 108, No. 8, (2000), pp. 652-659, ISSN 0002-9343

McCord, J.M. (2008). Superoxide dismutase, lipid peroxidation, and bell-shaped dose response curves. Dose Response, Vol. 6, No. 3, (2008), pp. 223-238, ISSN 1559-3258

Miles, B. (2003). Oxygen metabolism and oxygen toxicity, 06.05.2011, Available from http://www.tamu.edu/classes/

bmiles/lectures/Oxygen\%20Metabolism\%20and\%20Oxygen\%20Toxicity.pdf

Moosmann, B. \& Behl, C. (2002). Antioxidants as treatment for neurodegenerative disorders. Expert Opin Investig Drugs , Vol. 11, No. 10, (2002), pp. 1407-1435, ISSN 1354-3784 
Moreno, M.C.; Campanelli, J.; Sande, P.; Sanez, D.A.; Keller Sarmiento, M.I. \& Rosenstein, R.E. (2004). Retinal oxidative stress induced by high intraocular pressure. Free Radic Biol Med, Vol. 37, No. 6, (2004), pp. 803-812, ISSN 0891-5849

Moreno, M.C.; Sande, P.; Marcos, H.A.; de, Z.N.; Keller Sarmiento, M.I. \& Rosenstein, R.E. (2005). Effect of glaucoma on the retinal glutamate/glutamine cycle activity. FASEB J , Vol. 19, No. 9, (2005), pp. 1161-1162, ISSN 0892-6638

Nakazawa, T.; Shimura, M.; Endo, S.; Takahashi, H.; Mori, N. \& Tamai, M. (2005). N-MethylD-Aspartic acid suppresses Akt activity through protein phosphatase in retinal ganglion cells. Mol Vis , Vol. 11:1173-82., No. (2005), pp. 1173-1182, ISSN 1090-0535

Navarro, A. \& Boveris, A. (2009). Brain mitochondrial dysfunction and oxidative damage in Parkinson's disease. J Bioenerg Biomembr, Vol. 41, No. 6, (2009), pp. 517-521, ISSN 0145-479X

Ogawa, M.; Fukuyama, H.; Ouchi, Y.; Yamauchi, H. \& Kimura, J. (1996). Altered energy metabolism in Alzheimer's disease. J Neurol Sci , Vol. 139, No. 1, (1996), pp. 78-82, ISSN 0022-510X

Ohyagi, Y.; Yamada, T.; Nishioka, K.; Clarke, N.J.; Tomlinson, A.J.; Naylor, S.; Nakabeppu, Y.; Kira, J. \& Younkin, S.G. (2000). Selective increase in cellular A beta 42 is related to apoptosis but not necrosis. Neuroreport, Vol. 11, No. 1, (2000), pp. 167-171, ISSN 0959-4965

Oxford Dictionary of Sports Science \& Medicine (2007). Nitrosative stress, 25.09.2011, Available from http://www.answers.com/topic/nitrosative-stress\#ixzz1Yz0Phmmz

Parker, W.D., Jr.; Parks, J.K. \& Swerdlow, R.H. (2008). Complex I deficiency in Parkinson's disease frontal cortex. Brain Res , Vol. 1189:215-8. Epub@2007 Nov 1., No. (2008), pp. 215-218, ISSN 0006-8993

Pratico, D.; Clark, C.M.; Liun, F.; Rokach, J.; Lee, V.Y. \& Trojanowski, J.Q. (2002). Increase of brain oxidative stress in mild cognitive impairment: a possible predictor of Alzheimer disease. Arch Neurol , Vol. 59, No. 6, (2002), pp. 972-976, ISSN 0003-9942

Pratico, D.; Uryu, K.; Leight, S.; Trojanoswki, J.Q. \& Lee, V.M. (2001). Increased lipid peroxidation precedes amyloid plaque formation in an animal model of Alzheimer amyloidosis. J Neurosci , Vol. 21, No. 12, (2001), pp. 4183-4187, ISSN 0270-6474

Probiox (2011). What is Oxidative Stress?, 29.08.2011, Available from http://www.probiox.com/uk/pages/oxidative_def.html

Przedborski, S.; Jackson-Lewis, V.; Yokoyama, R.; Shibata, T.; Dawson, V.L. \& Dawson, T.M. (1996). Role of neuronal nitric oxide in 1-methyl-4-phenyl-1,2,3,6tetrahydropyridine (MPTP)-induced dopaminergic neurotoxicity. Proc Natl Acad Sci U S A, Vol. 93, No. 10, (1996), pp. 4565-4571, ISSN 0027-8424

Quigley, H.A. (1999). Neuronal death in glaucoma. Prog Retin Eye Res, Vol. 18, No. 1, (1999), pp. 39-57, ISSN 1350-9462

Resnikoff, S.; Pascolini, D.; Etya'ale, D.; Kocur, I.; Pararajasegaram, R.; Pokharel, G.P. \& Mariotti, S.P. (2004). Global data on visual impairment in the year 2002. Bull World Health Organ, Vol. 82, No. 11, (2004), pp. 844-851, ISSN 0042-9686

Rozemuller, A.J.; van Gool, W.A. \& Eikelenboom, P. (2005). The neuroinflammatory response in plaques and amyloid angiopathy in Alzheimer's disease: therapeutic implications. Curr Drug Targets CNS Neurol Disord, Vol. 4, No. 3, (2005), pp. 223233, ISSN 1568-007X 
Sacca, S.C.; Pascotto, A.; Camicione, P.; Capris, P. \& Izzotti, A. (2005). Oxidative DNA damage in the human trabecular meshwork: clinical correlation in patients with primary open-angle glaucoma. Arch Ophthalmol , Vol. 123, No. 4, (2005), pp. 458463, ISSN 0003-9950

Salganik, R.I. (2001). The benefits and hazards of antioxidants: controlling apoptosis and other protective mechanisms in cancer patients and the human population. J Am Coll Nutr, Vol. 20, No. 5 Suppl, (2001), pp. 464S-472S, ISSN 0731-5724

Schapira, A.H.; Cooper, J.M.; Dexter, D.; Clark, J.B.; Jenner, P. \& Marsden, C.D. (1990). Mitochondrial complex I deficiency in Parkinson's disease. J Neurochem , Vol. 54, No. 3, (1990), pp. 823-827, ISSN 0022-3042

Schwab, C. \& McGeer, P.L. (2008). Inflammatory aspects of Alzheimer disease and other neurodegenerative disorders. J Alzheimers Dis , Vol. 13, No. 4, (2008), pp. 359-369, ISSN 1387-2877

Selye, H. (1985). The nature of stress, 01.10.2011, Available from http:/ / www.icnr.com/articles/the-nature-of-stress.html

Sies, H. (1997). Oxidative stress: oxidants and antioxidants. Exp Physiol , Vol. 82, No. 2, (1997), pp. 291-295, ISSN 0958-0670

Sinet, P.M. (1982). Metabolism of oxygen derivatives in down's syndrome. Ann N Y Acad Sci , Vol. 396, No. (1982), pp. 83-94, ISSN 0077-8923

Sorce, S. \& Krause, K.H. (2009). NOX enzymes in the central nervous system: from signaling to disease. Antioxid Redox Signal , Vol. 11, No. 10, (2009), pp. 2481-2504, ISSN 1523-0864

Stanislawski, J. (1999). The Great English-Polish Dictionary. Philip Wilson, ISBN 83-7236-048-0, Warsaw

Steele, M.R.; Inman, D.M.; Calkins, D.J.; Horner, P.J. \& Vetter, M.L. (2006). Microarray analysis of retinal gene expression in the DBA/2J model of glaucoma. Invest Ophthalmol Vis Sci , Vol. 47, No. 3, (2006), pp. 977-985, ISSN 0146-0404

Tan, D.X.; Manchester, L.C.; Sainz, R.; Mayo, J.C.; Alvares, F.L. \& Reiter, R.J. (2003). Antioxidant strategies in treatment against neurodegenerative disorders. Expert Opin Ther Patents , Vol. 13, No. 10, (2003), pp. 1513-1543, ISSN 1354-3776

Tezel, G. (2006). Oxidative stress in glaucomatous neurodegeneration: mechanisms and consequences. Prog Retin Eye Res, Vol. 25, No. 5, (2006), pp. 490-513, ISSN 13509462

Tezel, G. (2011). The immune response in glaucoma: a perspective on the roles of oxidative stress. Exp Eye Res, Vol. 93, No. 2, (2011), pp. 178-186, ISSN

Tsang, A.H. \& Chung, K.K. (2009). Oxidative and nitrosative stress in Parkinson's disease. Biochim Biophys Acta , Vol. 1792, No. 7, (2009), pp. 643-650, ISSN 0006-3002

Turrens, J.F. (2003). Mitochondrial formation of reactive oxygen species. J Physiol, Vol. 552, No. Pt 2, (2003), pp. 335-344, ISSN 0022-3751

Uttara, B.; Singh, A.V.; Zamboni, P. \& Mahajan, R.T. (2009). Oxidative stress and neurodegenerative diseases: a review of upstream and downstream antioxidant therapeutic options. Curr Neuropharmacol , Vol. 7, No. 1, (2009), pp. 65-74, ISSN 1570-159X

Van Remmen, H.; Ikeno, Y.; Hamilton, M.; Pahlavani, M.; Wolf, N.; Thorpe, S.R.; Alderson, N.L.; Baynes, J.W.; Epstein, C.J.; Huang, T.T.; Nelson, J.; Strong, R. \& Richardson, A. (2003). Life-long reduction in MnSOD activity results in increased DNA damage 
and higher incidence of cancer but does not accelerate aging. Physiol Genomics, Vol. 16, No. 1, (2003), pp. 29-37, ISSN 1094-8341

Veal, E.A.; Day, A.M. \& Morgan, B.A. (2007). Hydrogen peroxide sensing and signaling. Mol Cell , Vol. 26, No. 1, (2007), pp. 1-14, ISSN 1097-2765

Wax, M.B.; Tezel, G. \& Edward, P.D. (1998). Clinical and ocular histopathological findings in a patient with normal-pressure glaucoma. Arch Ophthalmol, Vol. 116, No. 8, (1998), pp. 993-1001, ISSN 0003-9950

Wilcox, C.S. (2010). Effects of tempol and redox-cycling nitroxides in models of oxidative stress. Pharmacol Ther, Vol. 126, No. 2, (2010), pp. 119-145, ISSN

Winkler, B.S.; Boulton, M.E.; Gottsch, J.D. \& Sternberg, P. (1999). Oxidative damage and agerelated macular degeneration. Mol Vis, Vol. 5, No. (1999), pp. 32-42, ISSN 10900535

Wolf, C.; Gramer, E.; Muller-Myhsok, B.; Pasutto, F.; Reinthal, E.; Wissinger, B. \& Weisschuh, N. (2009). Evaluation of nine candidate genes in patients with normal tension glaucoma: a case control study. BMC Med Genet, Vol. 10:91., No. (2009), pp. 91-, ISSN 1471-2350

Wright, M.V. \& Kuhn, T.B. (2002). CNS neurons express two distinct plasma membrane electron transport systems implicated in neuronal viability. J Neurochem , Vol. 83, No. 3, (2002), pp. 655-664, ISSN 0022-3042

$\mathrm{Xu}, \mathrm{H}$; Chen, M. \& Forrester, J.V. (2009). Para-inflammation in the aging retina. Prog Retin Eye Res, Vol. 28, No. 5, (2009), pp. 348-368, ISSN 1350-9462

Yang, X.L. (2004). Characterization of receptors for glutamate and GABA in retinal neurons. Prog Neurobiol , Vol. 73, No. 2, (2004), pp. 127-150, ISSN 0002-9394

Yildirim, O.; Ates, N.A.; Ercan, B.; Muslu, N.; Unlu, A.; Tamer, L.; Atik, U. \& Kanik, A. (2005). Role of oxidative stress enzymes in open-angle glaucoma. Eye (Lond) , Vol. 19, No. 5, (2005), pp. 580-583, ISSN 0950-222X

Yoritaka, A.; Hattori, N.; Uchida, K.; Tanaka, M.; Stadtman, E.R. \& Mizuno, Y. (1996). Immunohistochemical detection of 4-hydroxynonenal protein adducts in Parkinson disease. Proc Natl Acad Sci U S A , Vol. 93, No. 7, (1996), pp. 2696-2701, ISSN 00278424

Zhang, J.; Perry, G.; Smith, M.A.; Robertson, D.; Olson, S.J.; Graham, D.G. \& Montine, T.J. (1999). Parkinson's disease is associated with oxidative damage to cytoplasmic DNA and RNA in substantia nigra neurons. Am J Pathol , Vol. 154, No. 5, (1999), pp. 1423-1429, ISSN 0002-9440 


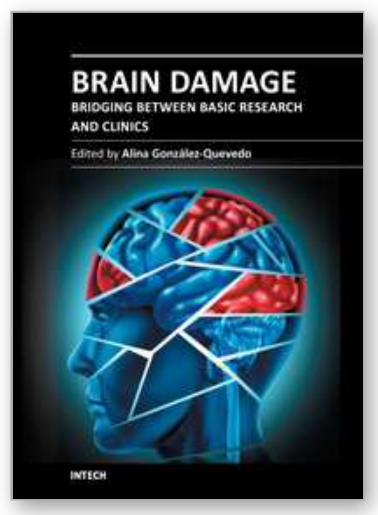

\author{
Brain Damage - Bridging Between Basic Research and Clinics \\ Edited by Dr. Alina Gonzalez-Quevedo
}

ISBN 978-953-51-0375-2

Hard cover, 282 pages

Publisher InTech

Published online 16, March, 2012

Published in print edition March, 2012

"Brain Damage - Bridging Between Basic Research and Clinics" represents a collection of papers in an attempt to provide an up-to-date approach to the fascinating topic of brain damage in different pathological situations, combining the authors' personal experiences with current knowledge in this field. In general, the necessary link between basic and clinical neurosciences is highlighted, as it is through this interaction that the theoretical understanding of the pathophysiological mechanisms can be successfully translated into better ways to diagnose, treat and prevent the catastrophic events that occur when the brain suffers from external or internal noxious events. The book spans different aspects of brain injury, starting from damage occurring in the fetal and child brain, followed by different neurodegenerative processes. Attention is also focused on the negative effects of drug addictions and sleep deprivation on the brain, as well as on the early assessment of brain injury for preventive strategies employing sensitive biomarkers.

\title{
How to reference
}

In order to correctly reference this scholarly work, feel free to copy and paste the following:

Michal Fiedorowicz and Pawel Grieb (2012). Nitrooxidative Stress and Neurodegeneration, Brain Damage Bridging Between Basic Research and Clinics, Dr. Alina Gonzalez-Quevedo (Ed.), ISBN: 978-953-51-0375-2, InTech, Available from: http://www.intechopen.com/books/brain-damage-bridging-between-basic-researchand-clinics/nitrooxidative-stress-and-neurodegeneration

\section{INTECH}

open science | open minds

\section{InTech Europe}

University Campus STeP Ri

Slavka Krautzeka 83/A

51000 Rijeka, Croatia

Phone: +385 (51) 770447

Fax: +385 (51) 686166

www.intechopen.com

\section{InTech China}

Unit 405, Office Block, Hotel Equatorial Shanghai

No.65, Yan An Road (West), Shanghai, 200040, China

中国上海市延安西路65号上海国际贵都大饭店办公楼 405 单元

Phone: +86-21-62489820

Fax: $+86-21-62489821$ 
(C) 2012 The Author(s). Licensee IntechOpen. This is an open access article distributed under the terms of the Creative Commons Attribution 3.0 License, which permits unrestricted use, distribution, and reproduction in any medium, provided the original work is properly cited. 